\title{
The Strategies of Novice Teachers' in the Large Class Management
}

\author{
Anisha Ayu Anindya, Ajeng Putri Nur Anisa, Akmal \\ Universitas Ahmad Dahlan \\ Email: aanishaayu@gmail.com
}

\begin{abstract}
This research reports which aimed to analyze strategies of novice teachers used in the large classroom management. This work is a comprehensive case study covering all teachers who play an important role in their classroom management. The case study on this research focused on Junior High School novice teachers in Yogyakarta. The researcher choose this school because it has large class that can support the researcher in collecting the data. The subject of this research consists of five novice teachers. The data was gathered through observation and interview. This study indicated the perspectives of the novice teachers in large classroom. The result showed that the teachers mostly divide or organize the students by grouping them, monitoring them to check students' work and to keep the class calm, give them positive punishment to students who misbehave, and using some teaching method to make students active during the teaching and learning process.
\end{abstract}

Keywords: novice teachers, strategies, large class.

\section{INTRODUCTION}

Teachers in education hold important role in classroom management which means that they must become a pillar that can stand up to help their students in learning (Halik et al. 2019). It helps student to know what they don't know before, and to be guidance in providing learning about moral values that can help them in shaping the character of each individual. In the school system, teachers are required to have good knowledge, skills, and competencies so that they can support their role in learning (Aswad et al. 2019). In any case the great educational programs, organization, and hardware offices, in the event that not adjusted by progressing the quality of the instructors will not bring the expected results. Teachers are exceptionally instrumental in making a difference the advancement of students to realize their life objectives ideally (Nurchalis, Leman, and Selle 2018).

One of the tasks that must be carried out by teachers in schools is to supply administrations to students so that they become students or students in agreement with the objectives of the school. The teacher's proficient competence could be a must in realizing knowledge-based schools (Rafiqa and Yasim 2019). To be specific information approximately 
understanding of learning, educational programs, and human improvement counting learning styles. In common in schools that have teachers with proficient competence will actualize "learning by doing" to supplant the way of teaching where the educator as it were talks and students as it were listen. Educators in Indonesia themselves are way better known as teachers, are instructive staff who take part in organizing instruction with extraordinary assignments as the educating calling. Teachers are individuals who in carrying out their obligations will confront and associated straightforwardly with their understudies in an orderly, arranged, and intentional prepare. Concurring to Drs. H. Abu Ahmadi and Drs. Widodo Supriyono, the teacher's part within the learning prepare is: (1) Teaching children by giving direction and inspiration to attain objectives, both short-term objectives and long-term objectives, (2) Giving satisfactory offices, media, learning encounters, (3) Offer assistance create perspectives of understudy identity, such as states of mind, values, and adjustment. Hence within the educating and learning process, the teacher isn't constrained to as it were passing on information but more than that, he is mindful for the generally advancement of student identity. He must be able to form a learning handle that's such that it can fortify students to memorize effectively and powerfully in assembly their needs and accomplishing objectives (Sieberer-Nagler 2015).

In Indonesian, many teachers still need the capacity to set up successful classroom management, especially utilizing nonverbal methodologies(Aswad 2017). The classrooms are frequently boisterous and difficult to handle. Thus, it is troublesome to conduct the learning handle effectively. This generally happens in novice teachers' educating handle, which still have need of encounters. Novice teachers too require offer assistance in managing with teaching challenges particular to their possess students' experienced teachers may be distinctive from novice teachers in different ways (Sözen 2019). They seem to need professional advancement that asserts the information, involvement, and instinctive judgment they have been cultivated amid their careers. A few experienced teachers are not as open to professional development as are modern teachers, indeed in spite of the fact that they might advantage from openings to reflect on and enhance their information and revive their excitement for educating. The term "novice" has frequently been used in ponders on fledgling teachers. As (Farrell 2012) states, there may be no exact definition of a beginner teacher within the existing literature. A novice may be anybody who is educating something modern for the to begin with time or who isn't continuously exceptionally familiar or experienced in instructing as a calling. There is also no agreement on how many a long time of instructing are vital to conclusion this novice organize.

To realize great classroom administration, a favorable and satisfying physical environment will bolster expanding student learning concentrated and have a positive impact on the accomplishment of educating destinations (Chaaban and Du 2017). Classroom administration isn't around learning courses of action, physical offices and schedules, but it prepares classroom conditions and the school environment to form a compelling and viable learning environment. Hence, schools and 
classrooms got to be overseen appropriately, and create a steady learning climate.

Managing class may be an expertise that must be had by the teacher in choosing, understanding, diagnosing and the capacity to act towards the progressing the classroom climate towards aspects of classroom administration. The aspects that ought to be considered in lesson administration are the nature of the lesson, the driving constrain of the course, the lesson circumstance, particular and imaginative activity.

Class management is all exercises of teachers within the lesson that make and keep up ideal conditions for the learning prepare (Bigelow 2000). Classroom management is different sorts of exercises that are continuously carried out by the teacher with the point of making and keeping up ideal conditions for the event of the learning prepare. (SiebererNagler 2015)

(Minh Trang 2015) Large class is a class with too much member of students. Teachers who normally teach 25-35 students will assume the class is huge when the teacher has to teach 50 or more students in one class so the big class can be sure of the experience of the teachers. Besides (Salwa 2015)in EFL settings, most teachers especially in school environments have to teach classes in which the learners have multiple levels of ability, since at schools, there is no

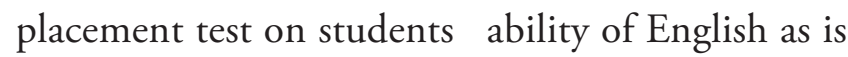
usually done in private language institutions. This paper provides some useful strategies which can be applied by teachers in teaching classes where true and false beginners are within the same class. Applying these strategies is expected to assist weaker students to get benefit from interacting with stronger students without holding back the strong ones. Teaching English in the EFL context needs more efforts and persistence since the target language (TL argues that a class of 30 students in one class is a large class. In addition, how many students were determined by student-teacher ratio, given in one class or per teacher.

In understanding with the requests of change, the teacher is additionally guided to have the capacity to adjust concurring to the requirements of the change. Changes within the educational modules include requiring teachers to be able to plan, actualize and adjust different needs within the teaching and learning handle in terms of hypothetical understanding, abilities in implementing learning in agreement with the educational modules in constrain and the capacity to conduct assessment exercises on the method it does.

\section{METHOD}

In this research, the researcher focus on novice teacher's strategies in managing the large class. The researcher use qualitative research with case study. According to Cresswell in (Almalki 2016), qualitative research is a process study that understands human or social problem to explain the sense of individual or group in social phenomenon occurs naturally. The qualitative relies on text and picture data, has complex problems, draws on different designs, offers detailed information and is performed in a natural environment. The aim of qualitative research is to gain an understanding of the human and social problem from multiple perspectives. 
This research was conducted in Muhammadiyah Junior High School. The researcher choose this school because it has large class that can support the researcher in collecting the data. The participant of this research consists of five novice teachers.

It's hoped the novices would instruct like experienced teachers (Liu and He 2014). It's clear that novices don't have the same credentials as the experienced teacher, but they have the same environment and sometimes they have a workload that is much more than an experienced teacher (Muthmainnah 2018). The subject of this research are five teachers who have experience less than one to three years.

In conducting this study, data collection techniques used are observation and interview. The observation was done while learning teaching and process takes place in order to know how the teacher run classroom management. After learning and teaching process ends, the interview was recorded using the mobile phone application to support the data collected from observation. The information collected from the checklist was used to explain and expand during interview.

There are four questions which are related to teacher's strategies and student's attitude. The data is transcribed from the observation pad, then coded and categorized. The data were then analyzed through a few interventions. The measures that include: transcribing audio recording data, categorizing data, and interpreting data based on goals and philosophy as well.

\section{RESULT}

\begin{tabular}{|l|l|l|l|}
\hline $\begin{array}{c}\text { Novice } \\
\text { teacher }\end{array}$ & $\begin{array}{c}\text { Length of } \\
\text { teaching } \\
\text { experience }\end{array}$ & gender & \multicolumn{1}{|c|}{$\begin{array}{c}\text { Teaching } \\
\text { context }\end{array}$} \\
\hline P1 & 3 years & Female & $\begin{array}{l}\text { Junior high } \\
\text { school }\end{array}$ \\
\hline P2 & $\begin{array}{l}2 \text { years, } 5 \\
\text { months }\end{array}$ & Female & $\begin{array}{l}\text { Junior high } \\
\text { school }\end{array}$ \\
\hline P3 & 7 months & Female & $\begin{array}{l}\text { Junior high } \\
\text { school }\end{array}$ \\
\hline P4 & 3 years & Female & $\begin{array}{l}\text { Junior high } \\
\text { school }\end{array}$ \\
\hline P5 & 1 year & female & $\begin{array}{l}\text { Junior high } \\
\text { school }\end{array}$ \\
\hline
\end{tabular}

For concentrate on the experiences of the inexperienced teachers in handling the classroom, the findings of the qualitative analysis to the data collected are presented here. The information gathered reflects their teaching experiences. Table 1. This was gathered from the portion of the interview which is used after making the observation as one of the instrument of this analysis.

Regarding to the purpose of the study, the discussion focuses on English teacher's classroom management for large class. The researcher conducted an interview to find out the methods used by the teachers in managing a large class in teaching English. The researcher interviewed five novice teachers who teach in Muhammadiyah Junior High School, the interview consists of eight questions showing the strategies of teachers in managing a large class of English teachers. The four questions represent teaching strategies and classroom management strategies of the teachers. The following explanation will show the result of interview. 
1. Strategies used by English teachers in the teaching and learning process, the teachers used six strategies; Conversation, Activities, Presentation, Individual Assignment, Team Plan, Question and Answer for Effective Learning as shown in the following figure;

\section{Question : What are strategies used by teacher's in teaching English?}

Based on the interview, some of novice teachers choose activities and team plan to make students enjoy the class.

"The strategies that i usually use in my class, activities to make them more active" (P1).

"I think the team plan also work in my class since $i$ use it so that the student can get close into each other" (P3).

Activities such as games make the students involve directly in learning while they can improve their vocabulary and pronounciation in english. Team plan, the students are divide into groups and each members of the group has their own responsibility to finish task from teachers. It trains solidarity among them. The aim to make students enjoy the lesson, understand it and obey it. Similar to the strategies employed by the English teachers, mostly all English teachers used activities (games) and team plan, as all participants agree.

2. Teacher strategies in arranging students during the learning process In managing students during the learning process, teachers commonly applied three strategies; organizing group students, giving individual tasks and reminding students to follow the rules of the class.

\section{Question : What do you do to manage students} when learning activities?

Based on the interview, some of novice teachers choose to divide the student into some groups. Moreover, the teachers give them group task when learning English.

"I usually divide the students by counting them or mixing them based on the attendant list, sometimes i give them some topics and ask them to choose the topic. After that, they discuss the topic and report the result in front of the class" (P5).

The teachers can control the students during the class easily and let them to share their knowledge and communicate between the members of group. The teachers also need to monitor or check students' work or to keep the classroom in a calm position. (Bahanshal 2013) believes that group work produces an interactive model of teaching or learning process where there is great interaction in the form of group work between teachers and students and among classmates. Additionally, teachers gave them specific tasks when learning English to eliminate noise in the classroom and alert the students to keep them focused on the lesson.

3. Treating Students' Destructive Behavior To regulate students' misconduct in the classroom, teachers usually used two techniques, such as give the students positive punishment and ask for help from counseling teacher. 


\section{Question : How do you deal with student who misbehave in the classroom ?}

Based on the interview, some of novice teachers choose to give the students positive punishment. This punishment is constructive so that the teachers do not need to scold the students.

"I give them positive punishment such as they have to buy others candy, to provide deterrent effect" (P2).

The teachers hand out positive punishment to make the students be reasonable and educating. This makes the students aware of or acknowledge the errors that they made. The punishment was given by the teacher not to make them afraid but was intended to give a deterrent effect so that in the future students will not repeat the same mistakes. Furthermore, the novice teachers also ask for help from counseling teacher in overcoming the problem of students who misbehave.

"To deal with students who misbehave, $i$ also often ask for help and support from the teacher in charge of counseling guidance" (P4).

The teachers can ask for help from counseling teachers. This strategy can be applied by novice teachers to improve the attitude of students who are often being naughty in the class. By the counseling teacher, the students are given motivation and reinforcement of character so that they will not repeat their actions and become discipline and obedient to their teachers. The novice teachers who do not have experience in overcoming this problems are usually still dependent on counseling teacher.

4. Teacher's efforts to improve the learning level of students.

Question : What do you do to make students always active during teaching and learning process?

Based on the interview, some of novice teachers choose to applied presentation and asking-answer method to stimulate them to be active in learning.

"I usually give them some questions and ask them to answer it. Furthermore, $i$ provide some texts and point them randomly to ask them to read the text in front of the class individually" (P1).

Progress in learning process is when students are able to give their teacher full attention as teacher needs to create a good atmosphere in the classroom environment during the classroom to make students interested in the subject and follow the lesson actively. In conjunction with this, the researcher identified two techniques widely used by novice teachers to enable students in learning activities, such as using a variety of methods and presenting and asking for answers.

In addition, from the fourth questions above, the researchers found that most of the teachers applied some strategies such as give them activities (games), team plan, applied presentation and asking-answer as their teaching strategies. Moreover, teachers primarily handle 
their students during the learning process, organize students into groups, review students by walking around the classroom to check students' work. Moreover, teachers who deal with misbehave students in the classroom, they applied some strategies such as give them positive punishment and ask help from counseling teachers, this aim to create detterant effect on students so that this particular behavior will not happen again. Each teachers have their own techniques, such as preparing him / herself, materials and media, using a variety of teaching methods, remaining in class during classes, beginning with warm-up activities.

\section{DISCUSSION}

\section{Research question: How do the novice teachers' face the problem of large class in teaching English?}

Large class is a class of over 30 to 50 students in one class and a different number of students in each region. Its say that what seems to matter is not the size of a class but the quality of the teaching, broad class depends on the context of control and teaching in the classroom itself. Carolyne \& Tchantchane (2010) said that the large class is a real challenge faced by every teacher and complicated in fact. Teachers deal with any kind of students, class environment management, lack of flexibility, difficulty in managing crowded students and behaviour, difficult to make relationships with students, hard-tomonitor learning groups, and not easy to encourage students in learning activities. It is undeniable that teaching large classes is a burden on teachers, especially beginner teachers because they may face many problems in their classrooms. (Keristiana and Fitriana 2019) outlines the main issues that other researchers had identified while teaching large classes. Watson said large class teachers often face problems in; Teaching strategies, management skills, ways to build good student-student interactions and friendly student-teacher relationships, teaching feedback and evaluation, marking students' papers.

It is very difficult for teachers to teach English in large classes to be more innovative in handling and building a class environment that is important for the learning process (Tok and Tok 2016). Training to teach English teachers uses a range of teaching techniques that can inspire and enthuse students in each training session. Both approaches involve students in communication and teamwork, working together through group discussions and characterized by performance-oriented learning. Apprentices work together, learn from each other and support each other. Students can also work alone at different times, for example when planning ideas before presentation and completing listening and writing tasks. Despite the large number of students in the classroom, researchers found that teachers often organize students into groups during classes, grouping students into groups is one of the goals in how teachers handle their class, group learning makes it easier for teachers to track most of the class action while studying or doing assignments, which saves teachers time.

Teachers also have their own methods to get classrooms to work well, such as organizing themselves, materials and media before teaching, 
remaining in class during lessons to coordinate classrooms and beginning classes with warm up activities. In addition, inspiring students to learn the instructor often uses methods of learning while doing it, organizing curriculum preparation to improve English performance, encouraging students to know basic English and rewarding students who complete their assignments.

\section{CONCLUSION}

Based on the result of the research, there are some strategies use by novice teachers in managing the large class in teaching and learning English. The strategies are; divide or organize the students by grouping them, monitoring them to check students' work and to keep the class calm, give them positive punishment to students who misbehave, and using some teaching method to make students active during the teaching and learning process. According to the students' perceptions against classroom management approaches used by English teachers, students perception has significant relationship between teachers strategies and students success in learning English. The teachers has effective approaches in managing their class and the students enjoyed.

\section{References}

Almalki, Sami. 2016. "Integrating Quantitative and Qualitative Data in Mixed Methods ResearchChallenges and Benefits." Journal of Education and Learning 5 (3): 288. https://doi.org/10.5539/jel. v5n3p288.

Aswad, Muhammad. 2017. "Is It Truly Improvisational Exercise Push Students' Speaking Ability." EDUVELOP (Journal of English Education and Development) 1 (1): 9-17.
Aswad, Muhammad, Fathu Rahman, I.M Said, B Hamuddin, and Nur Fadillah Nurchalis. 2019. "A Software to Increase English Learning Outcomes: An Acceleration Model of English as the Second Language." 2019. https://www.asian-efl-journal. com/monthly-journals/2019-monthly-journals/ volume-26-issue-6-2-2019/.

Bahanshal, Dalal A. 2013. "The Effect of Large Classes on English Teaching and Learning in Saudi Secondary Schools." English Language Teaching 6 (11): 49-59. https://doi.org/10.5539/elt.v6n11p49.

Bigelow, Lisa J. 2000. "Class Planning Strategies of Expert and Novice Teachers Novice Teachers." The Sloping Halls Review, 79-88.

Chaaban, Youmen, and Xiangyun Du. 2017. "Novice Teachers' Job Satisfaction and Coping Strategies: Overcoming Contextual Challenges at Qatari Government Schools." Teaching and Teacher Education 67 (October): 340-50. https://doi. org/10.1016/j.tate.2017.07.002.

Farrell, Thomas S.C. 2012. "Novice-Service Language Teacher Development: Bridging the Gap Between Preservice and In-Service Education and Development." TESOL Quarterly 46 (3): 435-49. https://doi.org/10.1002/tesq.36.

Halik, Abdul, St Wardah Hanafie Das, Muhammad Aswad, M. Syakir Rady, Muhammad Siri Dangnga, and M. Nasir S. 2019. "Empowerment of School Committee in Improving Education Service Quality at Public Primary School in Parepare City." Universal Journal of Educational Research 7 (9): 1956-63. https://doi.org/10.13189/ujer.2019.070915.

Keristiana, Trimar, and Rinda Fitriana. 2019. "Teachers 'Strategies in Managing a Large Class in Teaching English at SMP Negeri 01 Tanjung Selor" 1 (1).

Liu, Jiafeng, and Qingshun He. 2014. "Optimizing the Teaching Strategies of the Novice, Proficient and Expert College English Teachers." Creative Education 05 (13): 1119-24. https://doi.org/10.4236/ ce.2014.513126.

Minh Trang, Nguyen. 2015. "Large Classes: Universal Teaching and Management Strategies" 2 (1): 76-83. 
Muthmainnah, Siti Nafsul. 2018. "Gaya Mengajar Guru Pemula Dan Guru Profesional Dalam Pembelajaran Matematika Smp Di Klaten Teaching Styles of Novice Teachers and Professional Teachers of Mathematics in Junior Secondary School in Klaten" 3 (2): 202 16. https://doi.org/10.24832/jpnk.v3i2.896.

Nurchalis, Nur Fadillah, Ibrahim Leman, and Amzah Selle. 2018. "Lecturers' Consideration in Developing Language Tests:" EDUVELOP 2 (1): 20-36. https:// doi.org/10.31605/eduvelop.v2i1.79.

Rafiqa, Rafiqa, and Sukmawati Yasim. 2019. "Elevating the Pre-Service Teacher's Translation Skill Based on Learner Autonomy." EDUVELOP 3 (1): 14-20. https://doi.org/10.31605/eduvelop.v3i1.427.

Salwa, Salwa. 2015. "Considerable Strategies of Teaching Large Multi-Level Classes: A Narrative Study of What Efl Teachers Should Do." IJEE (Indonesian
Journal of English Education) 1 (1): 95-106. https:// doi.org/10.15408/ijee.v1i1.1197.

Sieberer-Nagler, Katharina. 2015. "Effective ClassroomManagement \& Positive Teaching." English Language Teaching 9 (1): 163. https://doi.org/10.5539/elt. v9n1p163.

Sözen, Pelin Hamurabi. 2019. "Challenges of Novice Teachers." IJAEDU- International E-Journal of Advances in Education, no. October: 278-82. https:// doi.org/10.18768/ijaedu.478254.

Tok, Türkay Nuri, and Şükran Tok. 2016. "Novice Teachers' Classroom Management Self Efficacy Beliefs." Journal of Human Sciences 13 (3): 5595. https://doi.org/10.14687/jhs.v13i3.4178. 